\title{
Rule of Law: Its Impact on Quality of Life
}

\author{
Noor Farihah Mohd Noor \\ College of Government, Law and International Studies (COLGIS), \\ University Utara Malaysia, \\ 06010, Sintok, Kedah Darul Aman, Malaysia \\ farihah@uum.edu.my
}

\begin{abstract}
Quality of life has very much to do with justice. Even though justice is hard to define but the basic idea remains that what is right is good and what is oppressive, is bad. So applying the same formula to all set of circumstances be it economy, social, and politics, will invigorate justice. The failure of world monetary system due to the crave for money and power has led the seekers to abuse and oppress the weaklings. The govt, financial institutions and commercial industries are no exception. Since justice is seen as obstacles to fast money and power, accountability have been regarded as a nuisance and justice is sidestepped and suppressed. Notion of Rule of Law emerge due to the need to address all these wrongdoings. Thus this paper seeks to discuss the problem underlying the situation and the means of overcoming it. One way is by imposing accountability and Rule of Law. Closely related to this issue too is the quality of life. Despite the increase standard of living; we still witnessed the glaring economic disparity between the rich and poor countries. Do this indicator project better living standard? Or it is measured from the view of the rich and the elite only? Hence this paper seeks to discuss that to implement justice there must be distribution of wealth and resources. What sensible person would deem as right, thus good. Apart from the western system that promotes Rule of Law, what is just and unjust has been clearly underlined by Islam. Man become just when they are able to restrict themselves from oppressing and tormenting others and Islam provide complete guidance to the existing crisis we faced now. Nevertheless we saw failures everywhere. They are due to the refusal of the followers to follow it, not the fault of the religion. It is attributed by their ignorance. This paper is important to show economy and social as well as quality of life devoid of justice stemming from manipulative capitalism and greed, are unsustainable and destructive. Unless and until this is understood, economic, political, environmental and social imbalances will never subside.
\end{abstract}

Keywords: Justice; Rule of Law, Accountability, Good Governance

\section{Quality of life: a sign of Rule of Law}

Many studies have shown that qualities of life were decoupled due to the monetary system that is destructive. The high cost of living all point out to the need to improve the situation. It has been shown that the monetary system that focuses on maximum profits has domino effects that incapacitated the society. The report revealed the following

In a report by The Financial Times, co-head of Asian economic research at HSBC Hong Kong Frederic Neumann said, "Household debt is a growth problem. The report warned that if debt became unsustainable and households deleveraged, it would affect consumer confidence and positive momentum, leading to a negative effect on economic growth (The Malaysian Insider, 2016). "If you look at primary market transaction, there'll be less launches this year, take-up rate will be lower, the oversupply that is in the property market, the overhang, will build up if you talk to the banks more auction and foreclosures of properties this year," Wong said during a press conference here today. National House Buyers Association (HBA) honorary secretary-general Chang Kim Loong also says Demographia's report house prices, especially in the urban and sub-urban areas, have risen beyond the reach of many average Malaysians (Malay mail, 2016)

Is quality of life simply measured by the standard of the rich or the opposite? Given such accountability and Rule of Law (ROL) are inevitable. It is popular principles to address the problem of inequality and disparity between the authorities and the subject as well as the rich and poor. It offers the people with the fair quality of life they deserve. 
For a country to have better quality of life there must be Rule of law. Rule of law not only demand legal justice to the community but extended beyond that. The govt owed a duty to provide its inhabitants with the proper quality of life. In order to achieve that, the govt must be held accountable for their actions. ROL exert accountability and impliedly restraint the govt from misusing the power. Powers more often were used to protect the rich and not the poor. Whilst in others impede public complaint of bad administration (The Malaysian Insider, 2016). This method of running a state has affected also the price of propriety to rise tremendously and tarnish the quality of life. Therefore, this paper will explain the danger of power that impedes accountability to be acquired and the role of ROL in limiting govt abusive conduct which is often eluded due to its capacity to cripple government's arbitrary power. It is the harm of unguided power and the rejection of any form of despotic government that gave rise to ROL and justice.

\section{Standard of Rule of Law}

$\mathrm{ROL}$ is synonym with justice. Justice lies in a subjective domain. No mention has been made on how this subjectivity can be maximized to increase or improved, the level of justice. Nevertheless despite the difficulties Australia has been seen to come up with initiatives to raise their standard of justice, whereas United Kingdom and United States likewise have made the requirements to be fair, a legal matter. The standard portrayed by other advance country shows that there is ROL. Apart from legal and social aspect, providing economic justice is also a reflection of ROL which illuminates the quality of life. Subsidies given to the people purportedly to the unfortunates are one way of addressing the problem. Question is, is it sufficient? The gap between the rich and poor are still prevalent in fact were getting wider and wider. The global financial fiascos were attributed to among others flawed credit rating agencies and blind regulators as well as avaricious, bonushungry bankers (The Guardian, 2016). How to narrow it down? Justice hence cannot be ignored when speaking of these economic gaps.

Given the above, not only in economy, justice is gravely needed and how regulators manage the financial system is also within public domain thus merits control. Justice is also marred in public setting. This obstacle is achieved by having a controlling body that scrutinizes any abuses of power. In legal sense manifestation of justice in UK and Australia is done via ombudsman. The wide power of ombudsman can be seen not only in reviewing legal error but actions that are unjust and in all circumstances, wrong. These are a reflection of broad content of administrative justice. Even actions and policies that are against Rule of Law can be subject to examination by the Ombudsman. It is sometimes inevitable that even proper conformity with law produces unacceptable result as it is not always easy to deal appropriately with constant changes of circumstances. That's why such power is given to the ombudsman to ensure accesses to justice are wide, supported and protected.

Trevor Buck and Richard Kirkham demonstrated that administrative justice has been extensively exercised in UK since 1967 inter alia through the establishment of ombudsman (Trevor buck, Richard Kirkham et al, 2011). The process has been ongoing since then. They asserted that administrative justice has been important to overall system of justice and because of that there is official faith in the ombudsman enterprise. With various review undertaken, proposal drawn up and reforms introduced, ombudsman enterprise was ignited. The development of admin justice apparatus inter alia can be seen from Lord Woolf's influential Access to Justice report (1996), The Leggatt Review of Tribunals (2001), the crucial government's white paper Transforming Public Service: Complaints redress and Tribunals (2004) and the transformation of the Council on Tribunals into the Administrative Justice and Tribunal Councils (AJTC) under the Tribunals, Courts and Enforcement Act 2007. Reforms continue to take place to complaint-handling arrangements as recommended in reports such as the Independent Review of Regulations and Inspection and Complaint Handling of public services in Scotland (Trevor buck, Richard Kirkham et al, 2011).

The same with Australia, all states in Australia have their own Ombudsman which thrives to incorporate the idea of admin justice more comprehensively. To name a few there are Commonwealth Ombudsman Act 1976, Australia Capital Territory Ombudsman Act 1989, New South Wales Ombudsman Act 1974, Northern Territory Ombudsman Act 2001, Queensland Ombudsman Act 2001, South Australia Ombudsman Act1972, Tasmania Ombudsman Act 1978, Victoria Ombudsman Act 1993 and Western Australia Parliamentary Commissioner 1971 (Trevor buck, Richard Kirkham et al, 2011).

The above illustrations provide brief understanding to the ways public powers are exercised and how concept of restricted government works to prevent the oppression. This information would inform us on how to deal appropriately with public flaws that spread across all level of government administration. The underlying governmental operations that bypass justice and accountability become the source of arbitrariness. These phenomena if allowed to flourish would inevitably lead to 
public deprivation and injustices. To combat this danger, the idea of restricted government embraced in the Rule of Just Law provides the people the right to encounter government unacceptable conducts. It is repugnant for government to deny this reality. These understandings are important to the government, not only in acquiring legitimacy and accountability but in securing its continuity.

\section{Rule of Law}

Many scholars have defined Rule of law in various angles. Some in ethical while others in legal sense. The root of Rule of law is actually divine in nature. Findings have shown that Rule of law has a divine standing. From divinity stems public good and ethics which later bred to more constitutional principles. This account was made by Aristotle. He claimed that law guided by divine rule will lead man to righteousness and reasons, unlike law by men, if unguided by just principles, are beastly.

Now absolute monarch and arbitrary rule of sovereign over all citizens in a city which consist of equals, is thought by some to be quite contrary to the nature ...that is why it is thought to be just that among equals everyone be ruled as well as rule and therefore that all should have their. And the Rule of law, it is argued, is preferable to that of any individual. On the same principle even if it be better for certain individuals to govern, they should be made only guardian of the law ...therefore he who bid the law rule may be deemed to bid God and reason alone rule, but he who bids man rule adds an element of beast; for desire is a wild beast and passion perverts the minds of rulers; even when they are the best of men. The law is reason unaffected by desire (Brian Z. Tamanaha, 2004).

Both Plato and Aristotle asserted law should further the good and enhance moral virtues of all citizens. Plato insists that law devoid of good and justice is bogus law. What is just is lawful and what is unjust is unlawful (Brian Z. Tamanaha, 2004). Thus for government, to be lawful it must be just, not the opposite. Justice is the prerequisite to accountability. Without accountability, justice is blind. That's why the passage of justice is founded in the divine nature which no man can construct without true guidance. A man is accountable when he is just and righteous. Justice is a subtle concept, controversial yet very useful to the people. Through justice, only can accountability deficit be addressed. Aristotle thus taught us to differentiate between just government and unjust government. He draw the line that, "true government will have just laws but bad government will have unjust laws".

Plato emphasized that law devoid of justice is a reflection of tyrannical government (Brian Z. Tamanaha, 2004). Government will be ruled by the best man not by rule of law. As a result, the law becomes rigid and meaningless to address clear or hidden injustices etc. Law in absence of just principles thus, is bad and repressive. It is justice that will steer the laws towards righteousness at all times. In fact to Plato where a good king rules, law is a hindrance standing in the way of justice like an obstinate and ignorant man. For Plato to avoid unjustness, Rule of law is needed to fill the human weaknesses of corruption and tyrannies.

\section{Harm of power that affects the quality of life}

The philosophy behind what justice stand for has led us the need to curb tyranny power. Undoubtedly the government exercises wide discretionary powers, in administering the state. Discretionary powers are inevitable. Its use is important for a modern government to function effectively. Characteristic of discretionary power are laid out in the statutes, express and implied. The statute books shows how wide ranging are the activities of states in matters of social welfare, public order, land use and resources planning, economic affairs and licensing. In all this matters increased discretionary power is displayed (DJ Galligan, 1986). Problems arise when these powers are abused. These disturbing trends are affirmed and agreed by many scholars. Many factors contribute to these flaws. Within this discretionary power lie policy choices. Policy choices are mostly unjust because choices are exercised within the rules not outside it. Joel Handler asserts that abuse happens when officials often conceal their choices behind the excuse of rules. Officials have a lot of choices (Joel Handler, 1992). Choices are made within legal boundaries to abuse, not to dispense justice. They exercise the conferred discretion often abusively. It is argued that it is the discretion that allowed the bargaining away of publicly defined normative standards and these will further disadvantage the weak and the powerless.

Shad Saleem Faruqi in the same tone admits that the levels of accountability deficit are alarming. Control mechanisms to measure accountability are not always effective. A wide gap exists between theory and reality, between promise and performance. In the legislative field, parliament legitimates government policies not legislate them (Shad Saleem Faruqi, 1995). Their controls on national expenditure are really inadequate because executives were allowed to spend large 
amounts of unauthorized public expenditure at will. The immunity of financial institution from scrutiny by Public Account Committee of the Dewan Rakyat and Parliamentary techniques of scrutinizing government administration are not sufficient be it on statutory bodies or privatized project. Privatized project receiving soft loans from the government and civil servant protected by doctrine of ministerial responsibility are abundant. In executive discretion, principle of openness and transparency are largely absent. Home Ministers power to grant licenses and permits for printing presses and publication and to impose "such condition as he deems fit", the grant of planning permission and alienation of state land to private individuals, grants of forest and sand concession, allocation of shares in government all are freely conferred without serious control.

Absolute power that corrupts, as such led to huge accountability deficit. Joel Handler thus asserted that without procedural protection on the poor and the weak, government agencies are prone to exploit the rules and create unfair advantage (Joel Handler, 1992). Many literatures as illustrated above showed exercise of discretionary power were unfairly exercised. Everyone is assumed to be relatively equal. Whereas everyone cannot be treated the same when discretion itself is unfairly applied. Discretion gave the official the choice to decide unfairly. In fact this is the main factor that causes discretion to be abused. Thus, this part will explain on how choices are manipulated in government administration.

Choices should work normatively through careful weighing of conflicting interest and needs, by giving regards to public concern. Discretion demands official to deal with the public especially the less dominant and the weak using values and norms so that they will not be unfairly disadvantaged. Yet, this is not what happened. The less dominant group are often badly disadvantaged as they lack the information, skills and power to persuade the authority. According to Joel Handler, this is "one among numerous forms of informal injustice." To him, neglecting and omission to account to the plight of unskilled and disadvantage person often produce injustice in an indirect or informal way. The officials can exercise unfair advantage because they can choose to consider the need of the powerful over the less fortunate group. It is a symbol of indirect oppression (Joel Handler, 1992). No doubt discretion is inevitable especially in human services agencies but it should be used to nurture public interest not manipulated to achieve private end. To avoid exploiting power advantages, there must be effective bargaining involving all parties especially the less dominant. Unfortunately powers are seldom exercised to uphold justice but exercised to suppress the weak. Joel Handler even claimed that poor clients get poor service and rich clients get better service.

This tendency is also affirmed by Norman Lewis and Patrick Birkinshaw (Norman Lewis and Patrick Birkinshaw, 1993). They asserted that if the dissatisfied client is persistent enough then he will get himself heard. On the other hand, if the poor and uninformed citizens approached, they will be told nothing of the opportunity of review of decision. Since decision for this type of group was rather low, therefore chances to have their case considered become slim too (Norman Lewis and Patrick Birkinshaw, 1993).

MP Jain also asserts that the poor onslaught of the government against the people is mirrored in how weak the citizen can be in the hand of the mighty government (MP Jain, 1997). The government has certain powers and privileges that put them above the citizen. Government can do a lot of good but at the same time a lot of damages too. It can choose to become a welfare state or a totalitarian state. So the question is not so much about the need for the state to have power but how to control them.

All these show accountability is a petite subject that can be manipulated at will. Thus, knowing what accountability stand for can help to improve justice and eventually increase the quality of life.

\section{Accountability increase quality of life}

Accountability and justice is synonym. Put it another way, in order to get justice the govt must be accountable. It is vague yet very important to all of us. Both terms are pertinently precious to man in order to lead a meaningful life. Justice is putting things at its rightful place. In administrative law context Trevor Buck et al expounded that 'justice is 'setting it right', to resolve dispute with the view to 'putting it right' and where failures in administration have been identified, to contribute to the process of 'getting it right' first time around by feeding back the public authorities knowledge and advice on good administration." (Trevor buck, Richard Kirkham et al, 2011). Besides the above suggestion, there are also other guidelines to be follow, to know what is rightful to do and not. There is no single method to pursue, so long as it create justice or the right equilibrium, it can be followed. The guiding principles that can be relied upon are numerous. For instance, besides accountability standards, admin law and the constitution provides principles and doctrines that can be used to gauge the 
extent of injustices espoused or justice omitted. There is no hard and fast rule to gauge injustices but indicator of abuse can be measured by the extent of corruptness, unfairness and unscrupulousness in public dealings. Making them accountable for such administrative flaws is what makes it just and fair. In other word, to be just one must be accountable. So if accountability promote justice then whatever means that is crucial to achieving accountability must be supported. If being responsive to the public cry is just then resolving it effectively constitutes accountability. Likewise if the purpose of complaint handling system is accessibility then providing easy access and effective remedy to the aggrieved denote justice. The two ideas are inseparable. To be just one must be accountable and to be accountable one must be just. This is how the two ideas merge together. The upshot is that they are significant in containing arbitrariness.

The guiding principles thus can be wide- ranging too and attempt to discuss everything under this part would be impossible. It is sufficient to show some background picture of what accountability stands for and the guiding principles it poses. If Prof Shad Saleem Faruqi claimed that controlling the government without crippling it, is the purpose of law, it is the same with Royal Commission investigation on commercial activities of government in Australia, to them accountability standards are not meant to prevent government from governing (Shad Saleem Faruqi, 1995). It would defeat the very purpose of power given by the constitution to the government, public officials and government agencies, to rule. The whole idea of imposing accountability standards to government, public officials and government agencies thus are to hold them responsible for their manner of stewardship (Robin Creyke and John McMillan, 2005). Even though power is given to the government to govern but it must not be misunderstood as being unbridled. The power is trust given by the people to the elected government. Accountability thus provides the test of that trusteeship (Robin Creyke and John McMillan, 2005).

Other guiding principle to make government answerable for their actions is that accountability must become the essentials to all public service. The methods of discharging accountability may vary but the core conditions of accountability i.e. justice remains. The rational is that when government is entrusted with public power to lead, the public is likewise entitled to reasonably expect from the government machineries, proper management and just use of powers. The expectation varies over time but the basic norms remains similar like compliance with the constitution; compliance with appropriate standard of official conducts, its justice, its efficacy, its economy, its effectiveness, its equity etc. All these expectations if appropriately address led to meaningful accountability.

The Australian Senate Select Committee gave its view of the guiding principle, though it is complex to translate them. It asserted that accountability is multi-faceted thus hard to define. Accountability is a notoriously imprecise term. It must be approached as a multi-level faceted problem encompassing more than one meaning. Balancing accountability with flexibility thus is the toughest challenge to public administration nowadays. Accountability requires rigidities yet in that rigidity, flexibility is needed so that justice can be dispensed with appropriately. For example, in order to innovate, take reasonable risks, and learn from mistakes, administrators need a degree of discretion and flexibility to act. Yet accountability for too many or unneeded rules and procedures can impede innovation and lead to inefficiency, ineffectiveness, and frustration. Certain basic rules and regulations, laws, and guidelines are indispensable to sound administration and accountability but they should be few, easily understandable, and consistently applied.

The Australian Senate Select Committee also gave a brilliant insight of what accountability should inter alia embrace. It asserted that public department must account for their performance and to achieve that they must be responsive to the legitimate interest of the affected parties. In other words, there is a duty of care. The citizens have the right to information about expenditure of public funds, how decisions are made as well as the capacity to question those decisions if it is ineffective.

In fact the need of accountability as the guiding principle is rooted from the higher law which is above parliamentary sovereignty as substantiated by Justice R Finkelstein,

Judicial review is more or less the enforcement of the Rule of law over executive actions. Like most of the common law, those statements go back at least to the writings of Edward Coke. In fact, Coke would have gone even further by promoting the idea (long since abandoned) that fundamental laws are superior to the kings (or in our case the legislatures) and that government answers to a 'higher authority.' (Justice R Finkelstein, 2006).

All the illustrations above show common attitude towards accountability though their focus differ from government to the aggrieved and from public to private rights but the spirit is the same i.e. to uphold justice. Accountability seeks not only to empower the government towards good administration but pertinently to help safeguard the people from the tyranny and 
oppressive conducts. The underlying idea is to uphold incorruptibility, accountability and fairness. In order to achieve such standard, the guiding principles of accountability expands also to values among others like openness, fairness, public participation, accountability, consistency, rationality, legality and morality must be instilled. Accountability thus involves wide scope of government responsibilities towards the people.

\section{Facets of ROL}

Since ROL promote justice thus ROL is the sign for better life. This is because the more just a govt is the more contented the people will be. Contentment reflects that the standard of govt service and product are satisfactory and pleasing. This part will demonstrate how ombudsman in Australia has led to better govt accountability and improved the quality of life of its people.

Australia ombudsman has projected how to uphold admin justice standard. Below are some of the report that reflects the sensitivity and high awareness of admin justice culture in Australia. The advance standard of admin justice in Australia was projected in 2005 and 2006 (Ombudsman Australia, 2005) The standard in 2012 is certainly much more sophisticated and advance. Table 1.1 is the report by Ombudsman office in 2005 and 2006 which indicate high observance of justice in Australia.

Table 1.1

Problem areas in government decision making

\section{UNHELPFUL LEGALISM}

Australian Government administration is bound by a large and growing volume of complex legislation. Lawyers and legal considerations will therefore have a role in resolving many disputed issues. Given that all administrators have a duty to act lawfully, they will often need legal guidance.

On the other hand, there is a growing risk that in the complex legal environment of government, legal approaches will overshadow the important role of administrative discretion and judgment in finding a practical resolution to problems. Although lawyers can make a positive contribution to administrative decision making, this does not mean that the more lawyers involved, the better the decision-making process.

The Ombudsman's office has often had cause to criticise unnecessary or unhelpful legalism by agencies. When agency lawyers become closely involved in deciding how to respond to the Ombudsman's office, there is a greater chance that jurisdictional and technical issues will be raised. Such issues include the scope of the Ombudsman's jurisdiction to investigate, the relevance of the Privacy Act 1988 to disclosure of information to the Ombudsman's office, the legal obstacles that would confront the agency in varying the decision about which a complaint has been made, or the broader ramifications for the agency of varying that decision. Those issues all have a role to play, but when they become the focus of discussion between the Ombudsman's office and an agency, more time can be spent discussing how to address a complaint than the complaint itself. The attention given to finer points and procedural issues can be at the expense of the whole picture and a discussion of outcomes and solutions.

'The Ombudsman's office has often had cause to criticise unnecessary or unhelpful legalism by agencies.'

There is a danger of a trend towards unhelpful legalism. There has been a steady increase in the number of lawyers in and outside government; all aspects of government are regulated to a greater extent by laws of increasing complexity; and legal considerations are intertwined with other social trends, such as an emphasis on risk management and human rights protection.

It is not easy to reduce the emphasis that agencies (and society generally) put on legal solutions and approaches. In a system based on the rule of law, there is no alternative to acknowledging and dealing with relevant legal issues raised in complaints or by agencies.

Nevertheless, our experience is that there is much to be gained by a readiness to stand back from any problem and to put legal issues to one side while discussion proceeds on other aspects of the problem. Sometimes, for example, a person's 
complaint about the correctness of a decision might in fact stem from some other dissatisfaction with an agency. Or there may be an acceptable way of working around the problem, or finding a remedy that will satisfy the complainant (such as an apology, a conciliation meeting, or payment of administrative compensation).

We have also found that some agencies are more likely than others to emphasise legal issues and limitations. Conversely, some agencies have been prepared to change their style of response to the Ombudsman's office when we have been critical of a trend towards legalism in the agency. This experience suggests that there is scope for agencies to adjust the emphasis they put on legal considerations in deciding how to resolve problems encountered by members of the public.

Similar concerns have at times been expressed by the Ombudsman's office to lawyers who have complained, either personally or on behalf of clients. Sometimes we find that lawyers' advocacy of complaints can be unduly strident or too focused on legal niceties. This can impede rather than assist the sensible and effective resolution of a complaint.

This is how justice is translated in Australia that impacted on good governance and ultimately, better quality of life of its people.

\section{Capitalism vs justice}

As mentioned above, accountability in Australia has been shown a success to the delivery of justice. If accountability standard has been satisfied, there is yet another puzzled that strikes our mind. How could high cost of living effect quality of life when it is these high cost that made the rich, richer? If so accountability standard are satisfying why is there rising cost of living. In fact it never decreases yet mounting nonstop. The high cost of life in reality was driven by the capitalist system. The capitalist system, for instance, is created with a purpose only to benefit the elite group. This in turn has caused a big gap between the rich and the poor. The so-called economic developments have caused more havoc than tranquility (Nik Mustapha, 2012). Among the many negative impacts were environmental degradation and unsystematic ways of managing nature and huge waste. The clearing of forests too has caused natural disaster like floods and global warming. Thus, when developments disregard nature, destruction ensues. To achieve justice therefore, man must uphold what is right and avoid evil (Nik Mustapha, 2012).

The damages can be seen again from the financial crisis we encountered today. The fall of Lehman brothers was contributed by the greed for money and competitiveness in business. In fact these have led to world crisis where USA controls the world's currency. Due to the drive of being super rich, Lehman has use LBO (leverage buyout) to prey on the victim. The insider of Lehman bro, Lawrence mc Donald revealed that there was too many leverage in the company that camouflage the failure and gave the false impression of its strength ( Lawrence Mc Donald, 2009). He asserted, 'money that was not real money, home price that were not real prices, mortgages that were not grounded in any definition of reality with which it is acquitted.' All this were due to false and unacceptable means of stimulating the economy. Unacceptable because they are demonstrably false and they are powerful because they make everyone feel richer and people believe they are richer. - the Lehman brothers for eg was buying 300 thousand mortgages package and making it into collateralise bond - $1 \%$ commission for 3 billion bundle of collaterised debts - this enable Lehman to obtain $1 \%$ commission for every sale made and those mortgages keep increasing. The harm arose when mortgage holder were unable to afford payment. The money was not founded on real means with which it is supposed to be thus the collapse.

The greed does not end there. Being the legions for home owners is not enough, Lehman took the chance of taking-over debts or leverage loan and trying to buy overweight US corporation. And there are powerful demands for leverage loans globally. The common victim targeted is corporation that were claimed as weak in management, unable to maximise profit and evoked for bad management. Leverage buyout takeovers are often predators and hostile. The buyer armed with borrowed cash from firm such as Lehman start buying up the stock in enormous quantities until they gain control of the shares. They then take over the company private and start selling off the asset and repay both the interest and the loan from the profit of the original corporation which could be saved and did not need change of ownership in the first place. For eg Leverage Buyout of Mervyns' department stores for 1.2 billion which they had force up 800 million debt on the company as soon as it was purchase and paid 400 million to themselves as dividend. But no one knew about it (Lawrence Mc Donald, 2009). 
These unjust and inhumane patterns of managing money have spread to other parts of the world. Malaysia is no exception. All these have led to severe rise of cost in all aspect of life that resulted in ruining the quality of life of the less fortunate and the like. The suffering is also felt by middle income group equally. Unless proper system is in place the quality of life of people especially the destitute will remain the same, in fact worsen.

\section{Reform}

Thus there must be morality in law governing the monetary system. That's why Costaz Douzinas opposed that legal structure is the only expression of ethical values as if justice is self-embedded in the law, whereas it is not. That's why Douzinas criticized when values are replaced with blanket certification of forms, "normativity has forfeited its claim to substance and values." (Costas Douzinas \& Adam Gearey, 2005).

Alexander Solzhennitsyn at Harvard also agreed that laws without justice are barren and empty. In fact Islam is the one that promote the morality of law. He forcefully averted that

Islamic values system stress on truth, justice, brotherhood. The real success is through hard work. This is the truth. The desire for a short cut thru unethical means does not satisfy the demand of truth. A society based on letter of laws will never reach any higher becuase it fail to take advantage of full human possibilities. A letter of law is too cold and formal to have beneficial in society. Whenever the tissue of life is woven with legalistic relationship it creates an atmosphere of spiritual mediocrity that paralyses men noble impulses (Nik Mustapha, 2012).

Robert Baldwin also concurred that the use of rules only strengthens abuse not otherwise. Rules may increase level of discretion and choices. When wide choices are given to the administrators, abusive choices are free and uncontrolled. It is unlikely the outcome of regulatory process will lead to efficiency because resources are displace and disproportionately distributed due to abusive and partial choices (D.J Galligan, 1986).

Given the above scenario and since the conventional system has bring about hardship to mankind especially to the poor and underprivileged, turning to Islam might shed light to overcoming the misery of the people in the world. The basic aim of Islam is to ensure well-being (Falah) of its followers in this world and in the Hereafter, and also to establish brotherhood among the members of the Muslim community (Ummah). This aim cannot be achieved if distribution of wealth among the members of Muslim community is uneven, the gulf between the rich and the poor is very wide and class conflict exists in the society. Therefore, the economic system of Islam tries to establish fair and equitable distribution of wealth among the members of the Muslim community by taking very effective measures. Al-Qur'an, the revealed book of Islam, declared in unequivocal terms:" That it (wealth) become not a commodity between the rich among you."(59:7). It means that the wealth should not form a circuit among the rich only, rather it should remain in circulation amongst all the members of the community meeting the genuine needs of all. That is why the Quran has strongly condemned, with threats of punishment, those who hoard wealth. "They who hoard up gold and silver and spend it not in the way of Allah, unto them give tidings ( $O$ Muhammad) of a painful doom."(9:34) (Muhammad Sharif Chaudhry, 1999).

The means of Equitable Distribution among others is zakat, which is compulsory levy or tax collected from rich by the Islamic state or the community and distributed to or spent on the poor. The relevant verses of the Qur'an pertaining zakat is in (Chapter 2, v 43). Establish worship, pay the poor-due, and bow your heads with those who bow (in worship). The hadith of Muhammad (PBUH) also strengthen this, Abdullah-bin-Amr reported that the Messenger of Allah said: Zakat is not lawful for the rich, nor for one possessing health and strength (Tirmizi Abu Daud). Here it is clear the money of the rich is to be shared and support the less wealthy. One way among others is to narrow the gap between the rich and poor hence refining the quality of life of all living soul.

In summary for the monetary system to be effective it must be just to all types of people especially to the poor. If the law governing the public and private fiscal fail to address this, in there lies the harmful effect. Returning back only to the original state of justice will ensure social, economic and political sustainability that will finally improve the quality of life. 


\section{Conclusion}

The basic working of ROL and justice have been portray. The upshot is that the accountability standard is imperative. The better it is implemented the better the quality of life of the people. This paper is unique as it has highlighted the importance of justice in stimulating good governance that ultimately improves the quality of life of not just the rich but the poor. It is a good indicator to show that the more rigorous justice principles are applied the higher the quality of life. It also indicates that for the law to be effective it must be just. It is not a vehicle of the rich and powerful to oppress the people. Even though Islam has laid the appropriate measures to address the problem but we are still witnessing the problem and failures. This is due to the ignorance of its followers to translate them. Man become just when they are able to restrict themselves from oppressing and tormenting others. Unless and until this is understood, economic, political, environmental and social disaster will never subside. It is not surprising to find the quality of life as empty and worthless, they are the reactions of man's own doing, and their greed and selfishness spurred from unbalance economic system, lack of justice and accountability and unbridled capitalism.

\section{References}

(2016, February 8). Malaysia's economic growth at risk as household debt soars. The Malaysian Insider, retrieved from http://www.themalaysianinsider.com/malaysia/article

Angie Ng. (2014, October 25). Demography: Malaysia's residential housing market 'severely unaffordable'. The Star, retrieved http://www.themalaysianinsider.com/malaysia/article

Mayuri Mei Lin (2016, January 20 ). Property experts say home prices to dip due to lower demand, supply 'overhang'. Malay mail, retrieved from http://www.themalaymailonline.com/malaysia/article/

(2016, February 9). Perkasa concerned over A-G's 'sudden' plan to tweak OSA. The Malaysian Insider. Retrieved from http://www.themalaysianinsider.com/malaysia/article/

Andrew Clark. (2016, January 9). Bankers played a leading role in the crisis, but they aren't criminals. Retrieved from http://www.theguardian.com/business/2011/mar/05/inside-job-oscars-banking-prosecutions

Nik Mustapha, N. H. (2012): An Islamic Paradigm in Economics: Vision and Mission. IKIM, Kuala Lumpur, Malaysia.

Trevor buck, Richard Kirkham et al. (2011): The Ombudsman Enterprise \& Administrative justice. Ashgate, 11.

Aristotle taken from Brian Z. Tamanaha (2004): The Rule of Law, History \& Theory. Cambridge University. Press, 9.

DJ Galligan (1986): "Discretionary power: A legal study of Official discretion. Clarendon Press, p. 344.

Joel Handler (1992): "Discretion: Power, Quiescence and Trust" in The Uses of Discretion edited by Keith Hawkins. Clarendon Press Oxford, 331.

Shad Saleem Faruqi (1995): Principles and Methods for Enforcing Accountability in the Public Sector, PhD Thesis, 376.

Norman Lewis and Patrick Birkinshaw (1993): When Citizens Complaint: Reforming Justice and Administration. Open University Press, 52.

MP Jain (1997): Administrative Law of Malaysia and Singapore 3rd Edition. Malayan Law Journal, 13.

Trevor buck, Richard Kirkham and Brian Thompson (2011): The Ombudsman Enterprise \& Administrative justice. Ashgate, 91.

Robin Creyke and John McMillan (2005): Government Action: Text and Commentary. LexisNexis Butterworths, 5.

Jeremy Waldron (2008): The concept and the Rule of law. The Ombudsman Enterprise \& Administrative justice (ed) Trevor buck, Richard Kirkham et al. Ashgate, 2011.

Justice R Finkelstein (2006): Paper delivered at Melbourne for Victoria Institute of Admin Law. 
Ombudsman (2006). Retrieved from www.ombudsman.gov.au.

Nik Mustapha, N. H. (2012): An Islamic Paradigm in Economics: Vision and Mission. IKIM, Kuala Lumpur, Malaysia.

Lawrence G. Mc Donald (2009): A Colossal Failure of Common Sense - The Inside Story of the Collapse of Lehman Brothers. Crown Publishing.

Costas Douzinas \& Adam Gearey (2005): Philosophy of Justice. Hart Publishing.

Nik Mustapha Nik Hassan (2005): "Management Principles from the Islamic Perspective." Quality Standard from The Islamic Perspective (ed) Mazilan Musa \& Shaikh Mohd Saifuddeen Shaikh Mohd Salleh. IKIM.

R. Baldwin and C.McCrudden (1986): "Regulatory Agencies: n Introduction, Conclusions: Regulation and Public Law." Administrative Law (ed) D.J Galligan. Oxford University Press.

Muhammad Sharif Chaudhry (1999): Fundamentals of Islamic Economic System. Burhan Education and Welfare Trust. 